\title{
Regulation of RhoA activity by the cellular prion protein
}

\author{
Hee-Jun Kim ${ }^{1}$, Hong-Seok Choi ${ }^{1,2}$, Jeong-Ho Park ${ }^{1,2}$, Mo-Jong Kim ${ }^{1,3}$, Hyoung-gon Lee ${ }^{4}$, Robert Bob Petersen ${ }^{5,6}$, Yong-Sun Kim ${ }^{1,2}$, \\ Jae-Bong Park ${ }^{\star, 7}$ and Eun-Kyoung Choi ${ }^{*, 1,3}$
}

The cellular prion protein ( $\mathrm{PrPC}^{\mathrm{C}}$ ) is a highly conserved glycosylphosphatidylinositol (GPI)-anchored membrane protein that is involved in the signal transduction during the initial phase of neurite outgrowth. The Ras homolog gene family member $A(R h o A)$ is a small GTPase that is known to have an essential role in regulating the development, differentiation, survival, and death of neurons in the central nervous system. Although recent studies have shown the dysregulation of RhoA in a variety of neurodegenerative diseases, the role of RhoA in prion pathogenesis remains unclear. Here, we investigated the regulation of RhoA-mediated signaling by $\mathrm{PrP}^{\mathrm{C}}$ using both in vitro and in vivo models and found that overexpression of $\mathrm{PrP}^{\mathrm{C}}$ significantly induced RhoA inactivation and RhoA phosphorylation in hippocampal neuronal cells and in the brains of transgenic mice. Using siRNA-mediated depletion of endogenous $\mathrm{PrP}^{\mathrm{C}}$ and overexpression of disease-associated mutants of $\mathrm{PrP}^{\mathrm{C}}$, we confirmed that $\mathrm{PrP}^{\mathrm{C}}$ induced RhoA inactivation, which accompanied RhoA phosphorylation but reduced the phosphorylation levels of LIM kinase (LIMK), leading to cofilin activation. In addition, $\mathrm{PrP}^{\mathrm{C}}$ colocalized with RhoA, and the overexpression of $\operatorname{PrP}^{\mathrm{C}}$ significantly increased neurite outgrowth in nerve growth factor-treated PC12 cells through RhoA inactivation. However, the disease-associated mutants of $\mathrm{PrP}^{\mathrm{C}}$ decreased neurite outgrowth compared with wild-type $\mathrm{PrP}^{\mathrm{C}}$. Moreover, inhibition of Rho-associated kinase (ROCK) substantially facilitated neurite outgrowth in NGF-treated PC12 cells, similar to the effect induced by PrPC. Interestingly, we found that the induction of RhoA inactivation occurred through the interaction of $\operatorname{PrP}^{\mathrm{C}}$ with $\mathrm{RhoA}$ and that $\operatorname{PrP}^{\mathrm{C}}$ enhanced the interaction between RhoA and p190RhoGAP (a GTPase-activating protein). These findings suggest that the interactions of PrPC with RhoA and p190RhoGAP contribute to neurite outgrowth by controlling RhoA inactivation and RhoA-mediated signaling and that disease-associated mutations of PrPC impair RhoA inactivation, which in turn leads to prion-related neurodegeneration. Cell Death and Disease (2017) 8, e2668; doi:10.1038/cddis.2017.37; published online 16 March 2017

The activity of Rho GTPases (Rho, Rac, and Cdc42) is controlled by regulatory proteins that cycle between an inactive GDP-bound state and an active GTP-bound state. Rho GTPases are activated by guanine nucleotide exchange factors (GEFs), which catalyze the exchange of GDP for GTP. In contrast, GTPase-activating proteins (GAPs), which stimulate Rho GTPase activity, and Rho guanine nucleotide dissociation inhibitors (GDIs), which inhibit the exchange of GDP for GTP in the cytoplasm by forming a Rho-RhoGDI complex, induce inactivation state of these GTPases. ${ }^{1,2}$ Furthermore, the Rho-RhoGDI complex needs to be dissociated by GDI displacement factor (GDF) before Rho GTPases are activated by GEFs. ${ }^{3}$ Activated Rho GTPases stimulate effector proteins, such as Rho-associated kinase (ROCK), mDia, and p21-activated kinase (PAK). Rho GTPases have roles in a variety of cellular functions including cytoskeletal rearrangement. ${ }^{4}$ In particular, the Ras homolog gene family member $A(R h o A)$ and RhoA regulatory proteins (including p190RhoGAP and RhoGDI) participate in neuronal differentiation processes, such as neurite outgrowth, neuronal migration, axonal growth, and dendritic spine formation and maintenance. ${ }^{5}$ In addition, several studies have shown that RhoA inactivation is essential for neuronal morphogenesis. ${ }^{6,7}$ Application of C3 toxin (a RhoA inhibitor) or Y27632 (a ROCK inhibitor) and overexpression of dominant-negative mutant RhoA enhanced neurite outgrowth from PC12 cells in response to nerve growth factor (NGF), basic fibroblast growth factor (bFGF), and cAMP. ${ }^{8,9}$

The cellular prion protein $\left(\mathrm{PrP}^{\mathrm{C}}\right)$ is a cell-surface glycosylphosphatidylinositol (GPI)-anchored glycoprotein attached to the plasma membrane. ${ }^{10} \mathrm{PrP}^{\mathrm{C}}$ has been associated with various cellular functions, including the cell cycle, cell growth, cell proliferation, cell-cell adhesion, cell migration, and the maintenance of cell shape. ${ }^{11,12} \mathrm{PrP}^{\mathrm{C}}$ is strongly expressed in the central nervous system (CNS) and can act as a regulator of neuronal development, differentiation, and neurite outgrowth, which may depend on interactions with various regulatory proteins, including heparan sulfate proteoglycans, ${ }^{13,14}$ stressinducible protein-1, ${ }^{15}$ Grb2 protein, ${ }^{16}$ caveolin, ${ }^{17}$ neural cell adhesion molecules (NCAMs), ${ }^{18,19}$ and extracellular matrix (ECM) proteins. ${ }^{20,21}$ In addition, $\operatorname{PrP}^{\mathrm{C}}$ exerts its functions by interacting with several kinases, including Fyn, protein kinase $\mathrm{C}$

\footnotetext{
${ }^{1}$ Ilsong Institute of Life Science, Hallym University, Anyang, Republic of Korea; ${ }^{2}$ Department of Microbiology, College of Medicine, Hallym University, Chuncheon, Republic of Korea; ${ }^{3}$ Department of Biomedical Gerontology, Graduate School of Hallym University, Chuncheon, Republic of Korea; ${ }^{4}$ Department of Biology, The University of Texas at San Antonio, San Antonio, TX, USA; ${ }^{5}$ Department of Pathology, Case Western Reserve University, Cleveland, OH, USA; ${ }^{6}$ Departments of Neuroscience and Neurology, Case Western Reserve University, Cleveland, OH, USA and ${ }^{7}$ Department of Biochemistry, College of Medicine, Hallym University, Chuncheon, Republic of Korea ${ }^{*}$ Corresponding author: E-K Choi, Ilsong Institute of Life Science, Hallym University, 15 Gwanpyeong-ro, 170 Beon-gil, Anyang, Gyeonggi-do 14066, Republic of Korea. Tel: +82 31380 1893; Fax: +82 31388 3427; E-mail: ekchoi@ hallym.ac.kr

or J-B Park, Department of Biochemistry, College of Medicine, Hallym University, 1 Hallymdaehak-gil, Chuncheon, Gangwon-do 24252, Republic of Korea. Tel: +82 33248 2542; Fax: +82 33244 8425; E-mail: jbpark@ @allym.ac.kr Received 07.10.16; revised 18.12.16; accepted 10.1.17; Edited by M Agostini
} 
(PKC), protein kinase A (PKA), phosphatidylinositol-3-kinase (PI3K)/Akt, and extracellular regulated kinases (ERK1/2). ${ }^{22,23}$

Loss of $\mathrm{PrP}^{\mathrm{C}}$ function has been implicated in neuronal polarization and neurite outgrowth through the modulation of integrin-ECM interactions and the RhoA-ROCK-LIM kinase (LIMK)-cofilin signaling pathway. ${ }^{24}$ Recently, ROCK overactivation and ROCK-3-phosphoinositide-dependent kinase 1 (PDK1) complex formation were shown to contribute to the regulation of neuronal polarity and the generation of pathogenic prions. ${ }^{25}$ However, the functional interaction between $\mathrm{PrP}$ and RhoA-related signaling molecules remains unknown.

In this study, we investigated the relationships of $\mathrm{PrP}^{\mathrm{C}}$ expression with RhoA activity and neurite outgrowth. We demonstrated that $\operatorname{PrP}^{\mathrm{C}}$ induced neurite outgrowth by inactivating $\mathrm{RhoA}$ and that $\mathrm{PrP}^{\mathrm{C}}$-mediated $\mathrm{RhoA}$ inactivation may be achieved by the interaction of PrP with RhoA and/or p190RhoGAP, resulting in the phosphorylation of RhoA at Ser188.

\section{Results}

PrPC regulates RhoA activation and RhoA-mediated signaling. To determine whether the $\operatorname{PrP}^{\mathrm{C}}$ affects $\mathrm{RhoA}$ activity, a pull-down assay was performed with the glutathione-S-transferase (GST)-Rhotekin-Rho-binding domain (RBD) in the ZW13-2 (wild-type, WT) and Zpl3-4 (PrP knockout) mouse hippocampal neuronal cell lines (Supplementary Figure 1), as previously established. ${ }^{26}$ We found that the level of RhoA-GTP in PrP knockout Zpl cells was significantly higher than in control ZW cells (Figure 1a). We confirmed this result by re-introducing mouse $\operatorname{PrP}(\mathrm{mPrP})$ into Zpl cells, which exhibited lower RhoA-GTP levels than Zpl cells that expressed the empty vector alone (Figure $1 b$ ). These results suggest that $\operatorname{PrP}^{C}$ negatively regulates $R h o A$ activity in hippocampal neuronal cells.

To further investigate the signaling pathway of RhoA regulated by $\operatorname{PrP}^{C}$ expression, we determined whether $\operatorname{PrP}^{\mathrm{C}}$ modulates the RhoA-ROCK-LIMK-cofilin pathway. As shown in Figure 2, PrP knockout and siRNA-mediated knockdown of endogenous $\mathrm{mPrP}\left(\mathrm{si}-\mathrm{mPrP} \mathrm{P}^{\mathrm{C}}\right)$ cells exhibited less phosphorylated RhoA at Ser188 ( $p-R h o A)$, which negatively regulates RhoA activity by enhancing its interaction with RhoGDI and translocates RhoA from the membrane to the cytosol $^{27}$ with increases in phospho-LIMK1/2 (p-LIMK1/2) and phosphocofilin ( $p$-cofilin) (Figures 2a and b). Supporting these results, the re-introduction of $\mathrm{MPrP}$ reversed the changes in the levels of $p$-RhoA, $p$-LIMK1/2, and p-cofilin compared with Zpl cells expressing the empty vector alone, yielding a result similar to that observed for the ZW cells (Figure 2c).

To confirm these results, we examined the effect of PrPC expression on RhoA activity and on the phosphorylation levels of RhoA downstream proteins in the brains of three different types of mice: WT (C57BL/6J) mice, Tga20 mice that overexpress $\operatorname{PrP}^{\mathrm{C}}$ (Tga20), and Zürich I Prnp-deficient (Zürich I) mice that lack $\operatorname{PrP}^{\mathrm{C}}$. As expected, we observed an increase in RhoA-GTP level (Figure $3 a$ ) accompanied by a decrease in $p$-RhoA and increases in both $p$-LIMK1/2 and $p$-cofilin (Figure $3 b$ ) in the brains of the Zürich I mice compared with the brains of the WT and Tga20 mice. These findings suggest that the expression of $\mathrm{PrP}^{\mathrm{C}}$ inactivates RhoA activity a

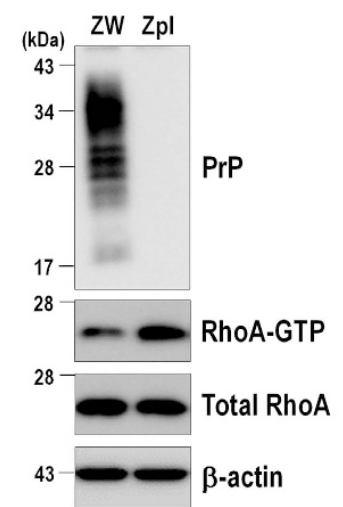

b
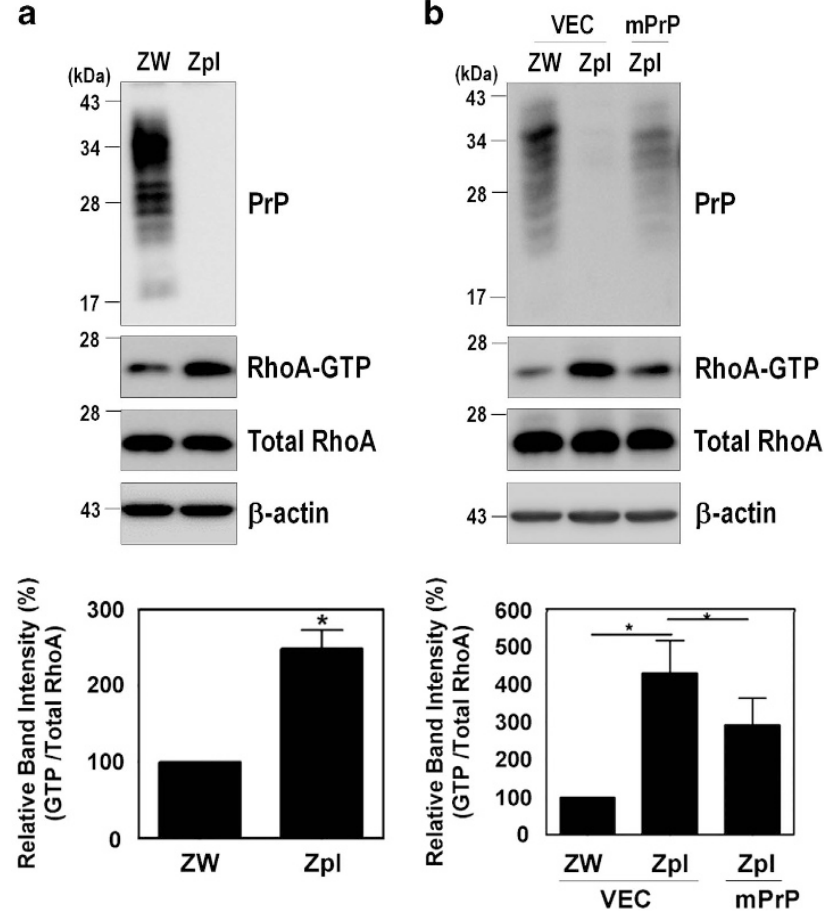

Figure $1 \operatorname{PrP}^{\mathrm{C}}$ regulates RhoA activation. (a and $\mathbf{b}$ ) Detection of RhoA-GTP by GST-Rhotekin-RBD pull-down assay in cells expressing $\operatorname{PrP}^{\mathrm{C}}(\mathrm{ZW})$ and PrP knockout (Zpl) with or without expressing mPrP. The level of RhoA-GTP was determined by western blot with anti-RhoA antibody following a pull-down assay. The data are expressed as the mean \pm S.E. of three independent experiments $\left({ }^{*} P<0.05, n=3\right)$

and subsequently affects its downstream regulatory proteins including LIMK and cofilin.

PrP $^{\mathrm{C}}$ controls F-actin formation through the RhoA/ROCK pathway. Previous studies have reported that RhoA activation has a role in the regulation of cytoskeleton reorganization through the formation of actin stress fibers and focal adhesions..$^{28,29}$ Thus, we investigated the effect of $\operatorname{PrP}^{C}$ on the formation of actin stress fibers in ZW and Zpl cells. Stress fibers were observed to form filamentous actin (F-actin), which was detected with fluorescein isothiocyanate (FITC)conjugated phalloidin. As shown in Figure 4a, F-actin formation was more strongly detected in Zpl cells than in $\mathrm{ZW}$ cells, and silencing $\operatorname{PrP}^{\mathrm{C}}$ in $\mathrm{ZW}$ cells markedly enhanced F-actin formation (Figure $4 b$ ). To confirm this finding, we determined the changes in G-actin and F-actin levels in ZW, $\mathrm{Zpl}$, and $\mathrm{Zpl}$ cells expressing $\mathrm{mPrP}$ using G-actin/F-actin sedimentation assay. Consistent with the results of $F$-actin formation, PrP knockout (Zpl cells) resulted in significantly increased F-actin sedimentation in the pellet fraction, whereas $\mathrm{G}$-actin levels were not changed in the supernatant fraction (Figure 4c). To further elucidate whether F-actin formation regulated by $\mathrm{PrP}^{\mathrm{C}}$ is due to RhoA-mediated signaling, cells were treated with Y27632, an inhibitor of ROCK. Interestingly, Y27632 treatment decreased F-actin formation in ZW cells (Supplementary Figure 2a). In addition, we analyzed $\mathrm{PrP}^{\mathrm{C}}$ on $\mathrm{F}$-actin-mediated cell adhesion using WST-1 reagent, which is a quantitative method for evaluating 

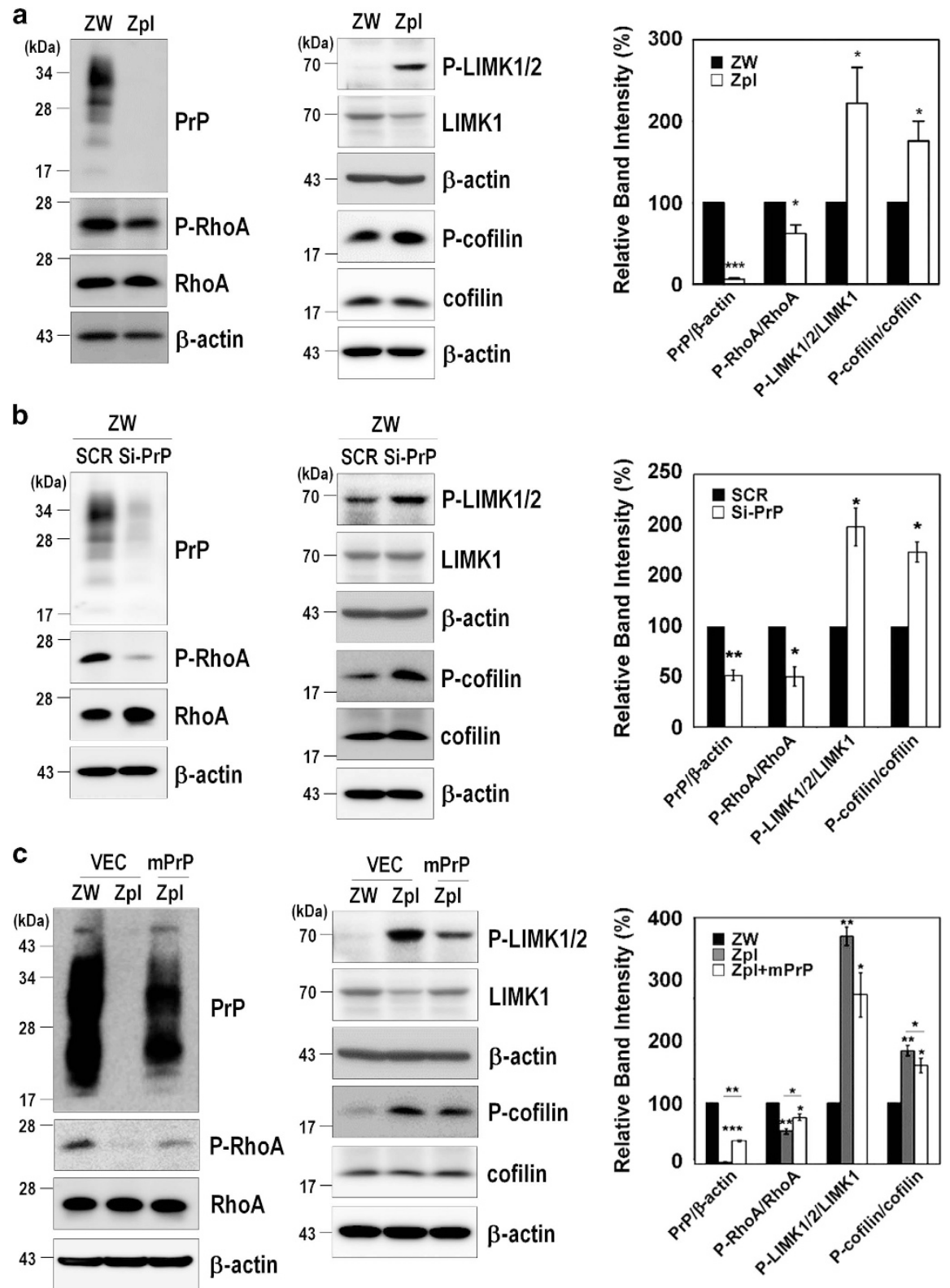

Figure $2 \mathrm{PrP}^{\mathrm{C}}$ modulates the RhoA-ROCK-LIMK-cofilin pathway. (a-c) Phosphorylation of RhoA, LIMK1/2, and cofilin in ZW and Zpl cells (a), in ZW cells transfected with scrambled RNA (SCR) or mPrP-targeted siRNA (Si-PrP) (b) and in Zpl cells with or without expressing mPrP (c) was analyzed in triplicate by western blot. The intensities of the bands in each panel were measured and quantified for each group, and the values are expressed as the mean \pm S.E. of three independent experiments ( ${ }^{\star} P<0.05,{ }^{* *} P<0.01$, $\left.{ }^{* * *} P<0.001, n=3\right)$

attached cells. In a cell adhesion assay, F-actin-mediated cell adhesion was significantly decreased in Zpl cells than ZW or Zpl cells expressing mPrP (Supplementary Figure 3). These findings indicate that $\mathrm{PrP}^{\mathrm{C}}$ is involved in F-actin formation and cell adhesion through the RhoA/ROCK signaling pathway.

PrPC interacts with both RhoA and p190RhoGAP. To identify the molecular mechanism by which $\mathrm{PrP}^{\mathrm{C}}$ induces RhoA inactivation, we sought to determine whether $\operatorname{PrP}^{C}$ and
RhoA directly interact in $\mathrm{ZW}$ and $\mathrm{Zpl}$ cells. As $\mathrm{PrP}^{\mathrm{C}}$ possesses a partial sequence homology with RhoA and RhoA effector proteins, including rhotekin, ROCK1, protein kinase $N(P K N)$, and rhophilin (Supplementary Figure 5), we confirmed the interaction of $\mathrm{PrP}^{\mathrm{C}}$ with $\mathrm{RhoA}$ using a co-immunoprecipitation assay in ZW cells (Figures 5a and $b$ ). To further verify whether the interaction between $\mathrm{PrP}^{\mathrm{C}}$ and RhoA occurs in the cytosol or membrane fractions in $\mathrm{ZW}$ cells, co-immunoprecipitation of $\mathrm{RhoA}$ and $\mathrm{PrP}^{\mathrm{C}}$ was 
a
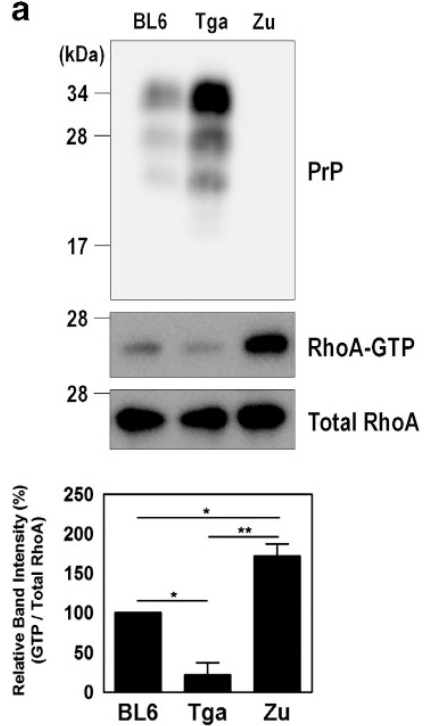

b

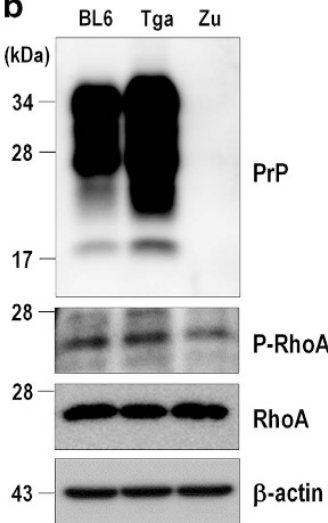

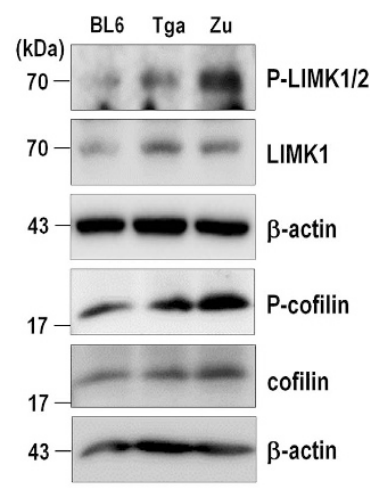

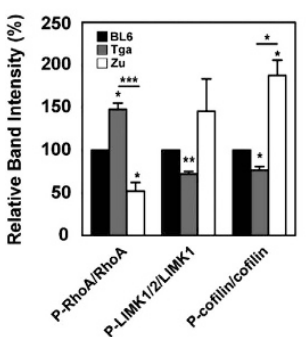

Figure $3 \mathrm{PrP}^{\mathrm{C}}$ is involved in RhoA inactivation in the brains of three different types of mice. (a) Detection of RhoA-GTP levels in the brains of C57BL/6J (BL6, WT), Tga20 (Tga, PrP overexpression) and Zürich I (Zu, PrP-deficient) mice ( $n=3$ per each group). (b) Phosphorylation of RhoA, LIMK, and cofilin was assessed in the whole-brain lysates of C57BL/6J, Tga20, and Zürich I mice. The data are expressed as the mean \pm S.E. of three independent experiments $\left({ }^{*} P<0.05,{ }^{* *} P<0.01,{ }^{* \star *} P<0.001, n=3\right.$ )

conducted on both fractions. As shown in Figure $5 \mathrm{c}$, the interaction between $\mathrm{PrP}^{\mathrm{C}}$ and $\mathrm{RhoA}$ in the membrane fraction was slightly increased compared with the cytosol fraction, although the level of RhoA in the cytosol fraction was higher than the level in the membrane fraction (Figure $5 b$ ). Furthermore, purified human recombinant $\mathrm{PrP}^{\mathrm{C}}$ protein directly bound to purified recombinant GST-RhoA protein in a concentration-dependent manner (Figure 5d). We also found that $\mathrm{PrP}^{\mathrm{C}}$ was colocalized with RhoA in the cytoplasm and the plasma membrane of $\mathrm{ZW}$ cells (Figure $5 \mathrm{e}$, arrowheads), suggesting that $\operatorname{PrP}^{C}$ directly interacts with $\mathrm{RhoA}$ in both the cytoplasm and the membrane.

As RhoA functions as a molecular switch between active GTP-bound and inactive GDP-bound states, we next investigated whether the GDP- or GTP-bound states of RhoA affect its interaction with $\mathrm{PrP}^{\mathrm{C}}$. ZW cell lysates were preloaded with either GDP or GTP $\gamma$ S, and then co-immunoprecipitation of RhoA with $\operatorname{PrP}$ was performed. We found that $\operatorname{PrP}^{C}$ preferentially interacts with active GTP $\gamma$ S-bound RhoA compared with GDP-bound RhoA in ZW cells (Figure 6a). In addition, the interaction of purified human recombinant $\mathrm{PrP}^{\mathrm{C}}$ with RhoA was also increased in the presence of GTP $\gamma$ S in ZPL cells (Figure 6b). These results showed that $\operatorname{PrP}^{\mathrm{C}}$ induced RhoA inactivation through a direct interaction with $R$ hoA in the cytosol and membrane fractions of $\mathrm{PrP}^{\mathrm{C}}$-expressing cells and that GTP-bound RhoA may more favorably interact with $\mathrm{PrP}^{\mathrm{C}}$.

The p190RhoGAP is known to be a major regulator of RhoA activity, ${ }^{30,31}$ it contributes to actin rearrangement and neurite outgrowth through binding to GTP-bound RhoA and subsequently enhancing the hydrolysis of GTP. ${ }^{32}$ Thus, we examined whether $\mathrm{PrP}^{\mathrm{C}}$ regulates $\mathrm{RhoA}$ inactivation by facilitating the interaction between RhoA and p190RhoGAP.
As expected, reducing $\operatorname{PrP}^{\mathrm{C}}$ expression by si-PrP ${ }^{\mathrm{C}}$ decreased its interactions with both RhoA and p190RhoGAP (Figure 6c). These findings indicate that $\operatorname{PrP}^{\mathrm{C}}$ interacts with $\mathrm{RhoA}$, as well as p190RhoGAP, and that $\operatorname{PrP}^{C}$ mediates the interaction between RhoA and p190RhoGAP.

The disease-associated $\operatorname{PrP}^{\mathrm{C}}$ mutants impair neurite outgrowth. Point mutations and polymorphisms of $\mathrm{PrP}^{\mathrm{C}}$ are associated with genetic prion diseases, ${ }^{33}$ and several studies have shown an association between the pathogenicity of prion diseases and neuronal differentiation. ${ }^{34,35}$ Therefore, we investigated whether the disease-associated mutations of $\mathrm{PrP}^{\mathrm{C}}$ affect NGF-induced neurite outgrowth in PC12 cells stably expressing WT or disease-associated mutants of $\operatorname{PrP}^{\mathrm{C}}$ (P102L and $\mathrm{M} \Delta 8$ ). Interestingly, the PC12 cells expressing WT $\mathrm{PrP}^{\mathrm{C}}$ exhibited enhanced neurite outgrowth and neurite length in response to NGF, whereas the cells expressing disease-associated $\mathrm{PrP}^{\mathrm{C}}$ mutants impaired neurite outgrowth and reduced neurite length (Figures $7 \mathrm{a}$ and $\mathrm{b}$ ). In addition, the inhibition of ROCK by Y27632 treatment significantly enhanced neurite outgrowth and neurite length (Figures $7 \mathrm{c}$ and $\mathrm{d}$ ). Using mutants of RhoA (S188D, mimicking the phosphorylated form; S188A, mimicking the dephosphorylated form), we found that RhoA phosphorylation (Ser188) induced neurite outgrowth in NGF-differentiated $\mathrm{PC} 12$ cells expressing $\mathrm{PrP}^{\mathrm{C}}$ (Supplementary Figure 4). These data indicate that $\operatorname{PrP}^{\mathrm{C}}$ may facilitate neurite outgrowth and affect the cellular signal transduction related to RhoA inactivation and that the phosphorylation of RhoA at Ser188 can also enhance $\mathrm{PrP}^{\mathrm{C}}$-mediated neurite outgrowth. 

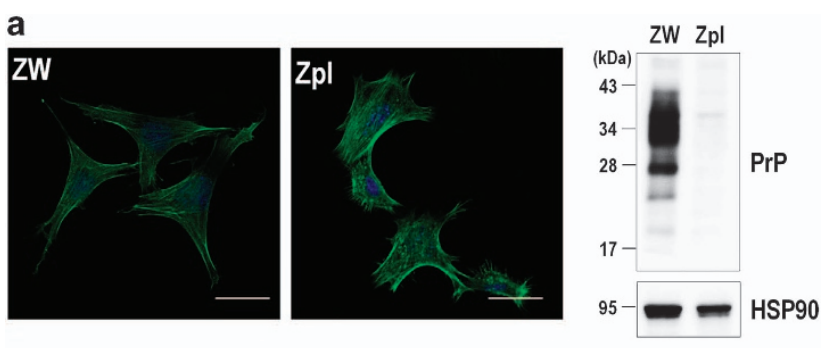

b
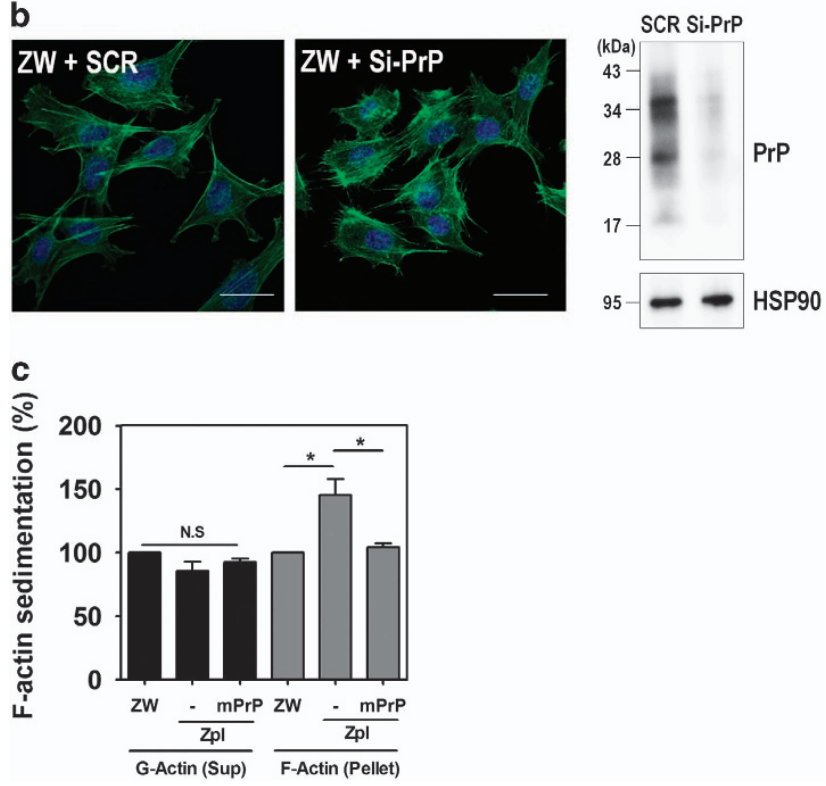

Figure 4 Depletion of $\mathrm{PrP}^{\mathrm{C}}$ increases $\mathrm{F}$-actin formation. (a and $\mathbf{b}$ ) Immunocytochemical staining for F-actin in ZW and Zpl cells (a), and ZW cells transfected with either scrambled RNA (SCR) or mPrP-targeted siRNA (Si-PrP) (b) using Alexa Fluor 488-phalloidin (green). DAPI (blue) was used to counterstain the nuclei. All pictures are representative of multiple images from three independent experiments (scale bars, $20 \mu \mathrm{m}$ ). The expression of $\operatorname{PrP}^{\mathrm{C}}$ was determined by western blot with anti-PrP (3F10) antibody and HSP90 was used as a loading control. (c) The expression of F-actin assessed by a sedimentation assay in ZW, Zpl, and Zpl expressing $\mathrm{mPrP}$ cells was analyzed by western blot with anti- $\beta$-actin, anti-PrP (3F10) and anti-HSP90 antibodies. The intensities of the bands in each panel were measured and quantified for each group, and the values are expressed as the mean \pm S.E. of three independent experiments $\left({ }^{*} P<0.05, n=3\right)$

The disease-associated mutations of PrPC affect RhoA signaling through reduced interaction with $\mathrm{RhoA}$ and p190RhoGAP. To investigate the effect of diseaseassociated mutations of $\mathrm{PrP}^{\mathrm{C}}$ on RhoA activity, PC12 cells were transiently transfected with an empty vector, WT $\operatorname{PrP}^{\mathrm{C}}$, or disease-associated mutants of $\operatorname{PrP}^{\mathrm{C}}$, and then treated with NGF. Interestingly, we observed that RhoA-GTP levels were increased in $\mathrm{PC} 12$ cells expressing disease-associated mutants of $\mathrm{PrP}^{\mathrm{C}}$ compared with the cells expressing WT $\operatorname{PrP}^{\mathrm{C}}$, although these changes were lower in the presence of NGF (Figure 8a). Interestingly, decrease in $p-R h o A$ and increases in both $\mathrm{p}$-LIMK1/2 and p-cofilin were detected in the cells expressing disease-associated mutants of $\mathrm{PrP}^{\mathrm{C}}$ compared with the cells expressing WT $\mathrm{PrP}^{\mathrm{C}}$ (Figure 8b). These results, which are correlated with those in PrP knockout or knockdown cells, indicate that $\operatorname{PrP}^{\mathrm{C}}$ regulates neurite outgrowth through inactivation of RhoA and the Rho/ ROCK signaling pathway. Next, we examined whether these disease-associated mutations of $\mathrm{PrP}^{\mathrm{C}}$ affect the interactions between not only $\operatorname{PrP}^{\mathrm{C}}$ and $\mathrm{RhoA}$ but also RhoA and p190RhoGAP. We found that the colocalization of PrP with RhoA was significantly decreased in the cells expressing disease-associated mutants of $\operatorname{PrP}^{\mathrm{C}}$ compared with cells expressing $\operatorname{PrP}^{\mathrm{C}}$ WT based on immunofluorescence staining (Figure 8c). Consistently, the co-immunoprecipitation of RhoA with the disease-associated mutants of $\mathrm{PrP}^{\mathrm{C}}$ was significantly decreased (Figure 8d). Moreover, the overexpression of disease-associated $\mathrm{PrP}^{\mathrm{C}}$ mutants markedly decreased its interaction with RhoA and p190RhoGAP (Figures 8e and f). Notably, the disease-associated mutations of $\mathrm{PrP}^{\mathrm{C}}$ reduced p190RhoGAP tyrosine phosphorylation, which led to a decrease in p190RhoGAP activity (Figure 8g). Taken together, these findings suggest that the diseaseassociated mutations of $\mathrm{PrP}^{\mathrm{C}}$ impaired RhoA signaling and the interaction with RhoA and p190RhoGAP.

\section{Discussion}

The physiological activity of $\mathrm{PrP}^{\mathrm{C}}$ in many important aspects of cell biology, including neuritogenesis and cell signaling, has been well established. ${ }^{24,25,36}$ Recent studies have demonstrated that $\mathrm{PrP}^{\mathrm{C}}$ contributes to neuritogenesis through modulating the $\beta 1$ integrin-coupled RhoA-ROCK-LIMK-cofilin signaling axis $^{24}$ and that prion-induced ROCK overactivation is involved in neuronal polarity and prion pathogenesis. ${ }^{25}$ However, it is still unclear whether $\mathrm{PrP}^{\mathrm{C}}$ can directly regulate RhoA activity, and its related effector proteins have not yet been elucidated.

In this study, we discovered a novel mechanism by which $\operatorname{PrP}^{\mathrm{C}}$ controls RhoA activity and the RhoA-mediated signaling pathway (Figure 8h). Both knockdown and silencing of $\mathrm{PrP}^{\mathrm{C}}$ induce activation of RhoA, which is best known for its function in reorganizing the actin cytoskeleton into stress fibers and focal adhesions, ${ }^{5}$ in concert with altered activities of downstream effector proteins (i.e., LIMK and cofilin). In addition, $\mathrm{PrP}^{\mathrm{C}}$ expression is also involved in the regulation of focal adhesion dynamics and actin polymerization. ${ }^{37,38}$ We also found that the depletion of $\operatorname{PrP}^{C}$ or the expression of diseaseassociated $\mathrm{PrP}^{\mathrm{C}}$ mutants impaired actin cytoskeleton dynamics and inhibited neurite outgrowth, possibly via increased phosphorylation of cofilin (an inactive form), leading to microfilaments that support stabilization. Unphosphorylated cofilin (an active form) is known to sever F-actin, resulting in depolymerization of $\mathrm{F}$-actin. ${ }^{29}$

The altered balance of cofilin activity is critical for the regulation of actin cytoskeleton dynamics and has been associated with neurodegeneration. ${ }^{39,40} \mathrm{NADPH}$ oxidase (NOX) is activated through a $\mathrm{PrP}^{\mathrm{C}}$-dependent pathway in response to proinflammatory cytokines, ${ }^{41}$ and the overexpression of $\mathrm{PrP}^{\mathrm{C}}$ alone also induced NOX-mediated ROS generation leading to the activation of cofilin and its oxidation (Cys39 and Cys147) followed by cofilin-actin rod formation. ${ }^{42}$ We found that overexpression of $\operatorname{PrP}^{\mathrm{C}}$ significantly reduced the amount of $p$-cofilin, leading to cofilin activation without changes in the total level of cofilin through the RhoA-ROCKLIMK-cofilin pathway, and led to increased neurite outgrowth 
a
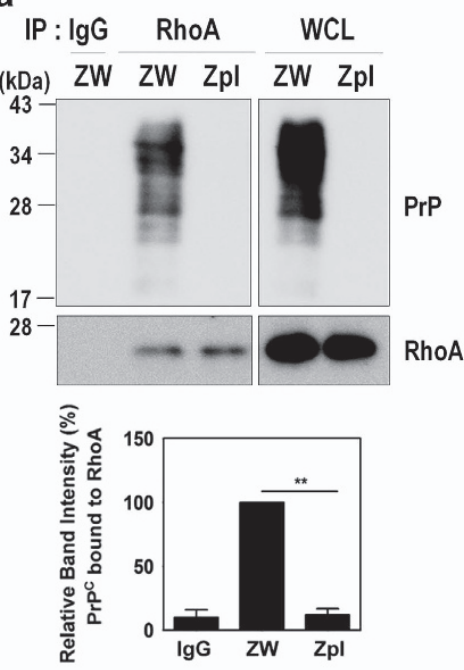

b

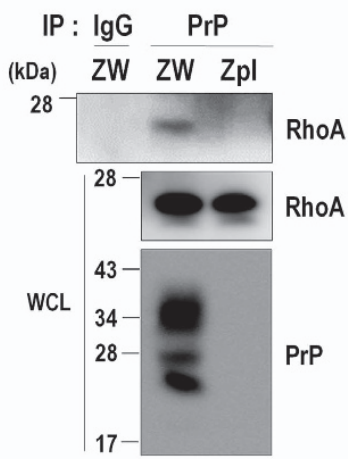

C
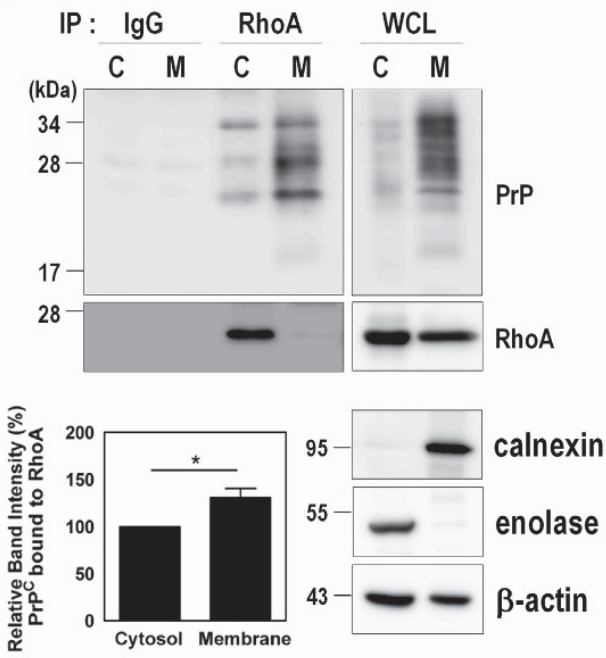

d

Beads : GST GST-RhoA

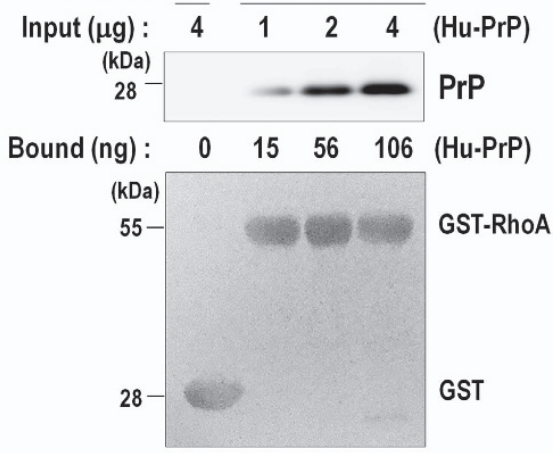

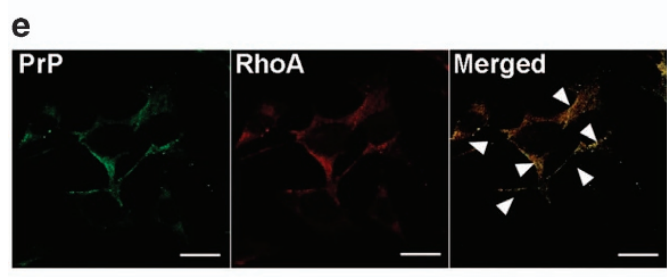

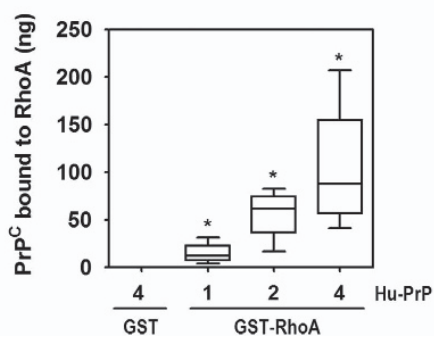

Figure 5 PrPC interacts with RhoA. (a and $\mathbf{b}$ ) Co-immunoprecipitation of PrP with RhoA using ZW and Zpl cell lysates were performed with either anti-RhoA (a) or anti-PrP (3F10) (b) antibodies, and then analyzed by western blot with anti-PrP and anti-RhoA antibodies, respectively. WCL, whole-cell lysates. (c) The subcellular fractions from ZW cells were used to immunoprecipitate RhoA with anti-RhoA antibody and then analyzed by western blot with anti-PrP (3F10) and anti-RhoA antibodies. Enolase and calnexin were used as makers for the cytosol (C) and membrane (M) fractions, respectively. $\beta$-Actin as a loading control. (d) GST and GST-RhoA beads were incubated with human recombinant $\operatorname{PrP}(\mathrm{Hu}-\mathrm{PrP})$ as indicated, and the level of Hu-PrP bound to GST-RhoA was determined by western blot with anti-PrP (3F4) antibody. The boxplot showing the means \pm S.E. of abundance of the PrP-RhoA complex, was calculated from the BSA standard curve in three $(n=3)$ independent experiments. The GST and GST-RhoA samples were stained with Ponceau $S$ to confirm the equal loading. (e) Colocalization of PrP with RhoA was assessed by double immunofluorescence staining and confocal microscopy. All above data are expressed as the mean \pm S.E. of three independent experiments $\left({ }^{*} P<0.05,{ }^{*} P<0.01, n=3\right.$ )

in NGF-treated PC12 cells. In addition, this regulation depends on the membrane environment and the interactions among membrane components (i.e., NOX isoforms, $\beta 1$ integrin, laminin, and fyn), resulting in $\mathrm{PrP}^{\mathrm{C}}$-dependent neuronal differentiation or synaptic dysfunction.

$\mathrm{PrP}^{\mathrm{C}}$ has been implicated in neurite outgrowth as an interacting partner with NCAM and laminin. ${ }^{18,19,43}$ In addition, several interacting partners have been reported to directly bind to $\operatorname{PrP}^{\mathrm{C}}$, which enhances brain development, neuronal differentiation, and neuronal cell death in various cell lines and animal models. ${ }^{13-21}$ Moreover, these interactions can regulate various signaling pathways, such as PI3K/AKT, ${ }^{22,44}$ ERK1/2,22,23 and RhoA/Rac1/Cdc42. ${ }^{12}$ Interestingly, the $\mathrm{PI} 3 \mathrm{~K} / \mathrm{Akt}$ and $\mathrm{ERK} 1 / 2$ pathways regulate transcriptional profiles that promote neurite extension. ${ }^{45}$ Activation of Rac1 and Cdc42 in conjunction with inhibition of RhoA 
a
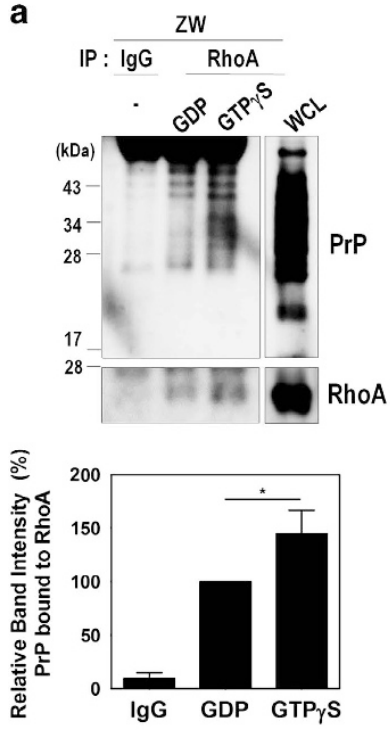

C

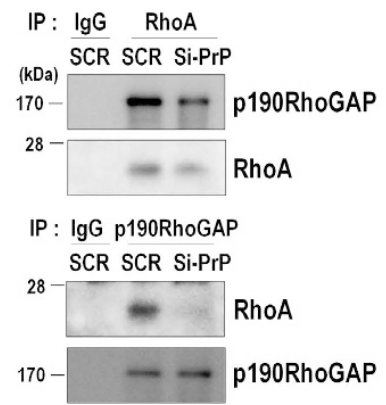

b
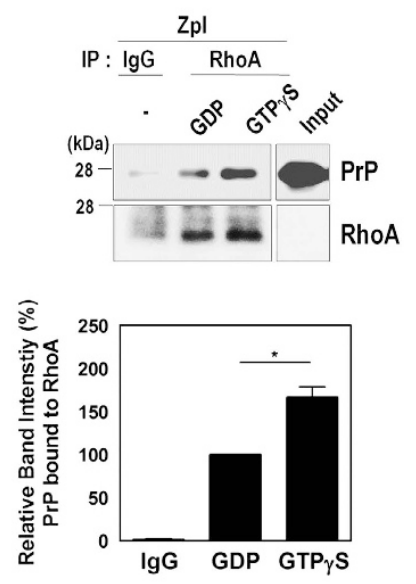

WCL

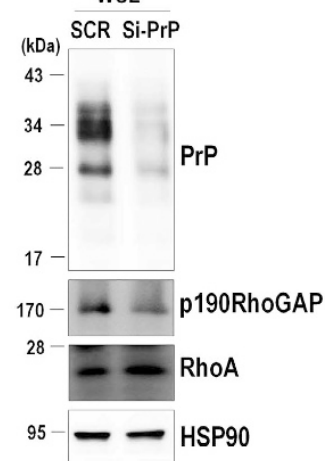

Figure $6 \mathrm{PrP}^{\mathrm{C}}$ binds to GTP-bound RhoA and p190RhoGAP. (a) ZW cell lysates were preloaded with GDP or GTP $\gamma S$ followed by immunoprecipitation with the antiRhoA antibody and analyzed by western blot using the anti-PrP (3F10) and anti-RhoA antibodies. WCL, whole-cell lysates. (b) Zpl cell lysates preloaded with GDP or GTP $\gamma$ S were immunoprecipitated with anti-RhoA antibody, incubated with $2 \mu \mathrm{g}$ of human recombinant $\operatorname{PrP}(\mathrm{Hu}-\operatorname{PrP})$, and analyzed by western blot with the anti-PrP (3F4) and anti-RhoA antibodies. (c) The co-immunoprecipitation of RhoA or p190RhoGAP using ZW cells transiently transfected with either SCR or Si-PrP was detected by western blot using anti-p190RhoGAP and anti-RhoA antibodies, respectively. The data are expressed as the mean \pm S.E. of three independent experiments $\left({ }^{*} P<0.05, n=3\right)$

activity increases neurite extension via posttranslational mechanisms - both pathways functionally connect with ROCK. ${ }^{46}$ We also demonstrated increased neurite extension and neurite length as a result of ROCK inhibition by Y27632, suggesting that $\operatorname{PrP}^{C}$ exerts its influence on neuronal differentiation by modulating RhoA-mediated signaling effectors (i.e., ROCK and p190RhoGAP).

Specifically, we demonstrated the biological consequences of $\mathrm{PrP}^{\mathrm{C}}$-mediated RhoA inactivation that results from the interaction of $\operatorname{PrP}^{\mathrm{C}}$ with RhoA and p190RhoGAP, and overexpressing $\mathrm{PrP}^{\mathrm{C}}$ results in increased tyrosine phosphorylation of p190RhoGAP, which elevates p190RhoGAP activity. Indeed, p190RhoGAP was reported to be activated through tyrosine phosphorylation by Src. ${ }^{47}$ In contrast, these results were not observed for the disease-associated mutants of $\operatorname{PrP}^{C}$. These findings suggest that $\operatorname{PrP}^{C}$ may have a role in both the phosphorylation of p190RhoGAP and RhoAp190RhoGAP complex formation.

p190RhoGAP is activated by the binding of $\beta 1$ integrins and then translocates into a detergent-insoluble fraction upon adhesion to fibronectin and colocalizes with F-actin in lamellipodial protrusions. ${ }^{30,48,49}$ Furthermore, integrin clustering triggers RhoA inactivation through $\mathrm{C}$-Src-dependent activation of p190RhoGAP, ${ }^{47}$ and p190RhoGAP-mediated RhoA inactivation effectively induces neurite outgrowth in PC12 cells. ${ }^{50}$ In addition, PKA phosphorylates RhoA at Ser188, resulting in its release from membranes through increased interactions with RhoGDI. ${ }^{51,52}$ Furthermore, the interactions between RhoA and RhoGDI were reported to negatively regulate the cycling of RhoA activity at the leading edge in migrating cells. ${ }^{53}$ We showed that overexpression of the RhoA S188D mutant but not the S188A mutant promoted neurite outgrowth in the NGF-treated PC12 cells expressing $\operatorname{PrP}^{\mathrm{C}}$. These data indicate that $\operatorname{PrP}^{\mathrm{C}}$ induced RhoA inactivation also through RhoA phosphorylation at Ser188. Furthermore, we demonstrated that $\operatorname{PrP}^{\mathrm{C}}$ is colocalized with RhoA and that it enhanced the interaction between RhoA and p190RhoGAP in response to NGF. However, the interacting domains of $\operatorname{PrP}^{\mathrm{C}}$ and RhoA remain to be elucidated. In general, active RhoA induced actin-myosin interactions, resulting in cell contraction, although inactive RhoA were reported to prevent actin-myosin interaction, which may induce cell expansion and neurite outgrowth. ${ }^{54}$

In prion diseases, genetic mutations of $\mathrm{PrP}^{\mathrm{C}}$ induce spongiform encephalopathy and spontaneous neurodegeneration, and the disease-associated mutations of $\operatorname{PrP}^{\mathrm{C}}$ lead to severe ataxia, apoptosis, and extensive central and peripheral myelin degeneration. ${ }^{55,56}$ As shown in this study, overexpression of the disease-associated mutants of $\operatorname{PrP}^{\mathrm{C}}$ (P102L and $M \triangle 8$ ) impaired neurite outgrowth because of the failure to inactivate RhoA and reduced the co-immunoprecipitation of RhoA and p190RhoGAP. Interestingly, scrapie infection increases RhoA activation by decreasing the interaction between RhoA and p190RhoGAP (manuscript in preparation). Based on these findings, the disease-associated mutations of $\mathrm{PrP}^{\mathrm{C}}$ and scrapie infection partially suppress neuronal differentiation via the failure to inactivate RhoA.

Taken together, our results showed that $\operatorname{PrP}^{\mathrm{C}}$ contributes to RhoA inactivation, leading to neuritogenesis and that diseaseassociated mutants of $\mathrm{PrP}^{\mathrm{C}}$ failed to inactivate RhoA, which in turn leads to prion-related neurodegeneration. These findings are important for understanding the mechanisms of $\mathrm{PrP}^{\mathrm{C}}$-mediated neuronal differentiation and survival.

\section{Materials and Methods}

Materials. Bovine serum albumin (BSA), Y27632, and the anti- $\beta$-actin antibody were purchased from Sigma-Aldrich (St. Louis, MO, USA). Anti-RhoA, anti-Rac1, anti-Cdc42, anti-RhoGDI, and anti-cofilin antibodies were obtained from Santa Cruz Biotechnology (Santa Cruz, CA, USA). NGF and the anti-p190RhoGAP antibody were purchased from Millipore (Lake Placid, NY, USA). Anti-p-RhoA (S188), anti-pLIMK1/2, anti-LIMK1, and anti-LIMK2 antibodies were purchased from Abcam (Cambridge, MA, USA). The anti-p-cofilin antibody was obtained from Cell Signaling Technology (Danvers, MA, USA).

Cell culture, transfection, and generation of stable cell lines. Mouse hippocampal neuronal cell lines, including ZW13-2 (WT PrP) and Zpl3-4 (PrP knockout) cells, were previously established. ${ }^{26} \mathrm{ZW}$ and $\mathrm{Zpl}$ cells were 
a
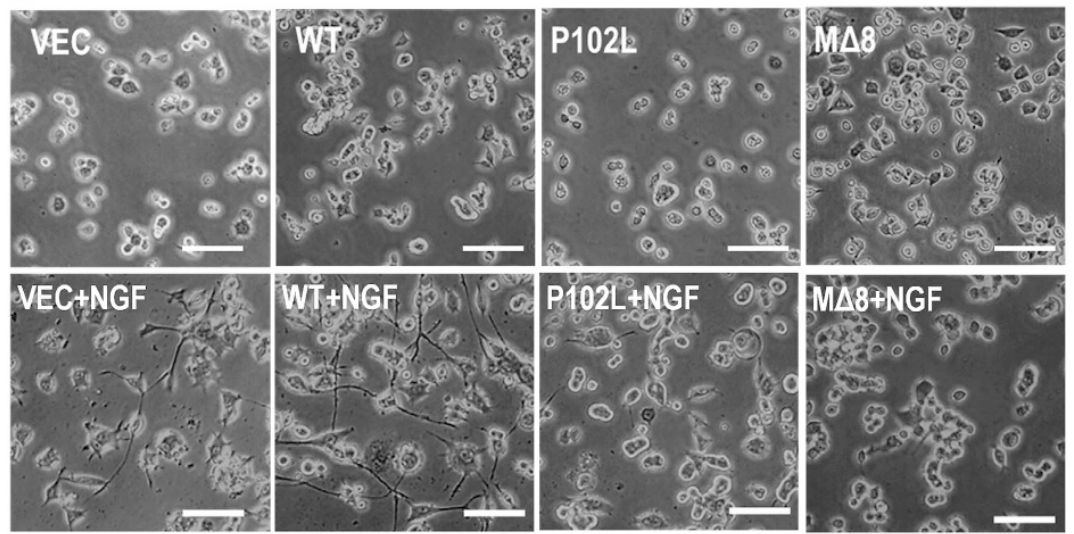

b
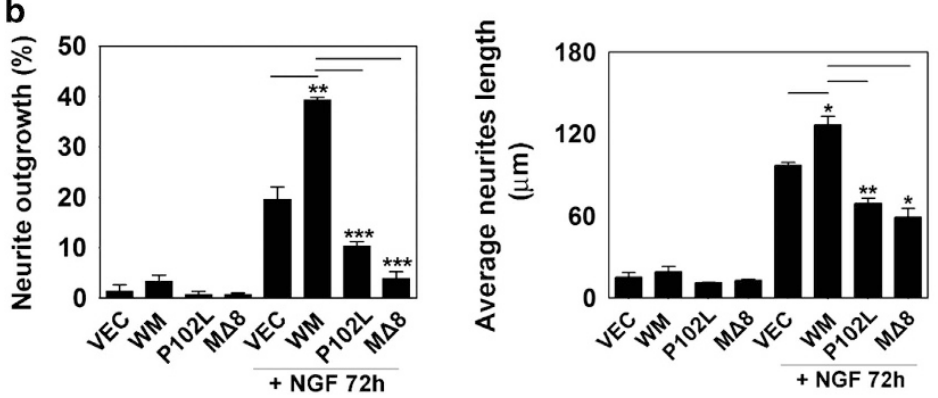

C

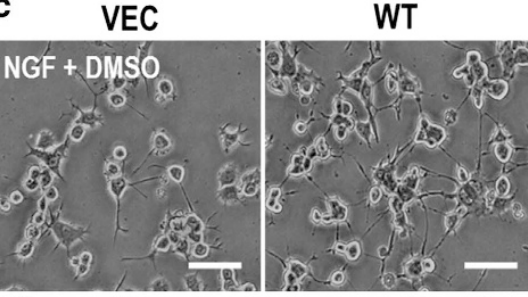

P102L
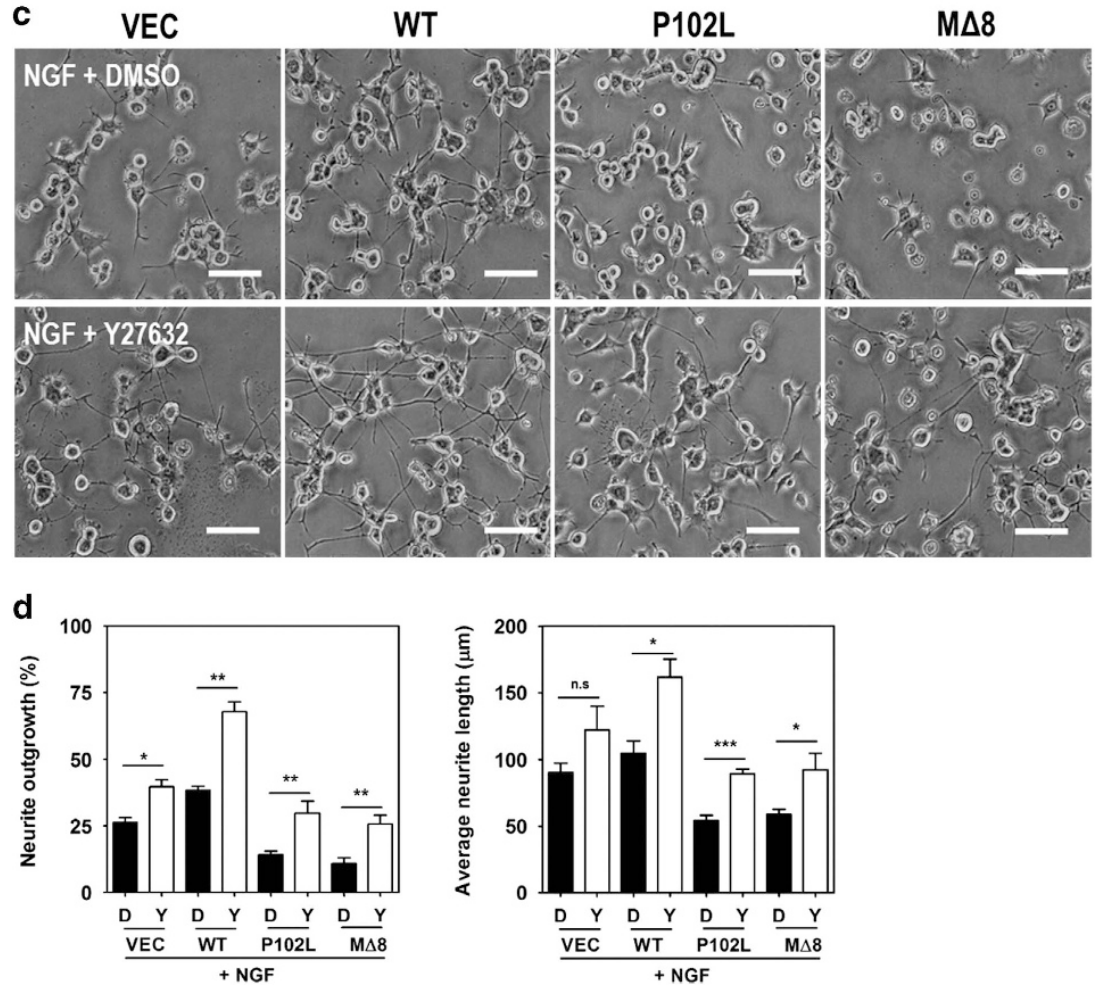

Figure 7 The disease-associated mutations of $\mathrm{PrP}^{\mathrm{C}}$ impair neurite outgrowth. (a and $\mathbf{b}$ ) PC12 cells stably expressing either vector, WT, P102L, or M $\Delta 8$ were treated with $50 \mathrm{ng} / \mathrm{ml} \mathrm{NGF}$ for $72 \mathrm{~h}$. (c and d) The cells expressing either vector, WT, P102L, or M $\Delta 8$ were incubated with or without $10 \mu \mathrm{M}$ Y27632 in the presence of NGF. Changes in the cell morphology, neurite length, and neurite numbers were determined under a microscope. The data are expressed as the mean \pm S.E. of three independent experiments $\left({ }^{\star} P<0.05,{ }^{* *} P<0.01,{ }^{* \star *} P<0.001, n=3\right)$ 
a
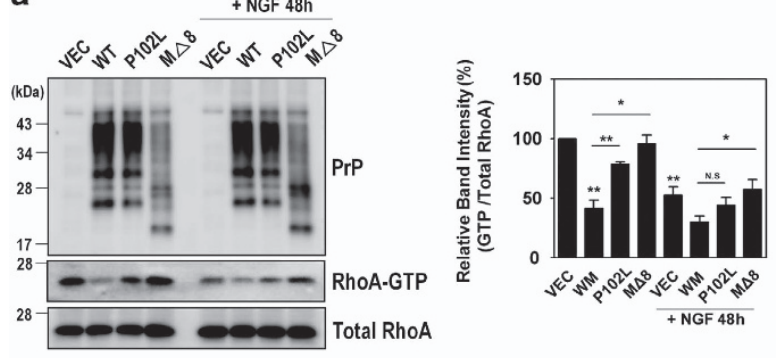

b
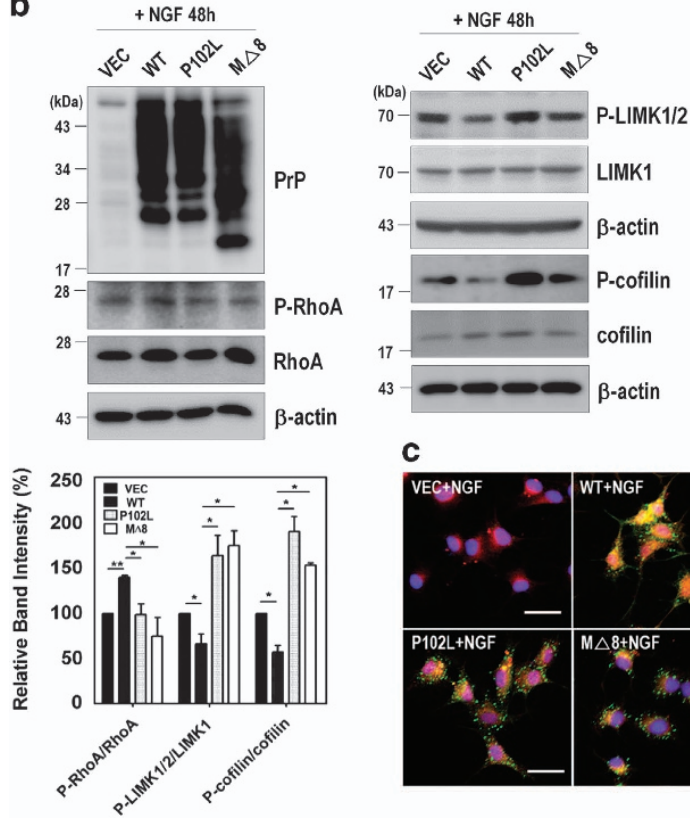

C

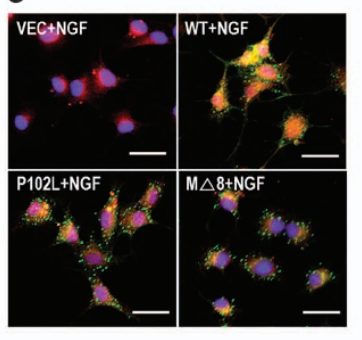

d
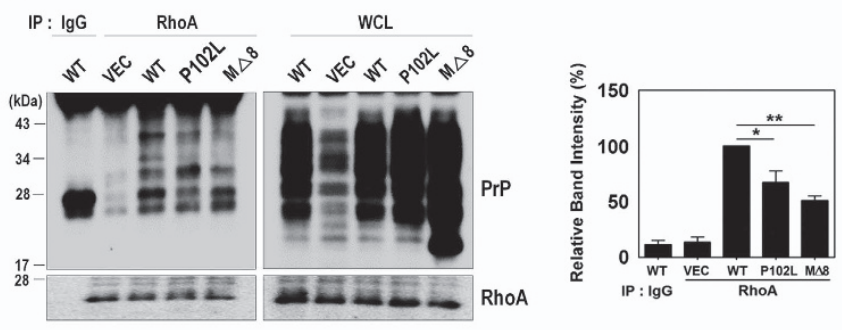

e

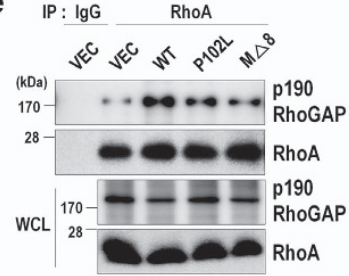

$\mathbf{f}_{\mathbb{P P}: \lg G \quad \text { p190RhoGAP }}$ g

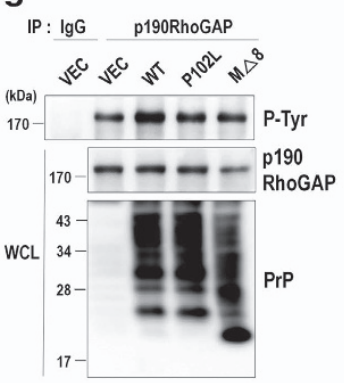

h

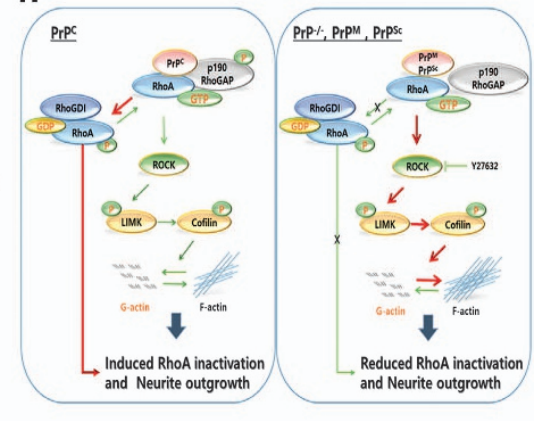

Figure 8 The disease-associated mutants of $\operatorname{PrP}^{\mathrm{C}}$ affect RhoA signaling through the reduced interactions with RhoA and p190RhoGAP. (a and $\mathbf{b}$ ) The level of RhoA-GTP following a pull-down assay (a) and the phosphorylation of RhoA, LIMK, and cofilin (b) was analyzed by western blot in PC12 cells expressing either vector, WT, P102L, or M $\Delta 8$ in response to NGF. (c) Colocalization of PrP with RhoA in the NGF-treated PC12 cells expressing either vector, WT, P102L, or M $\Delta 8$ was determined using confocal microscopy (green, PrP; red, RhoA; blue, DAPI). (d) HEK293 cells were transiently transfected with either vector, WT, P102L, or M $\Delta 8$. The co-immunoprecipitation of RhoA was detected by western blot using anti-PrP (3F4) and anti-RhoA antibodies. (e-g) PC12 cells transiently transfected WT or disease-associated mutants of PrPC were lysed and immunoprecipitated with anti-RhoA (e) and p190RhoGAP antibodies (f). (g) The p190RhoGAP phosphorylation (p-Tyr) was detected using p-Tyr antibody after p190RhoGAP immunoprecipitation. All above data are expressed as the mean \pm S.E. of three independent experiments $\left({ }^{\star} P<0.05,{ }^{* \star} P<0.01, n=3\right)$. (h) PrPC - RhoA interaction stimulates RhoA inactivation and neurite outgrowth. In PrPC-expressing cells and mice, PrPC increased the phosphorylation of RhoA and p190RhoGAP, enhancing the interaction between RhoA and p190RhoGAP. This complex led to the inactivation of RhoA and its downstream effectors. Subsequently, RhoA inactivation decreased actin polymerization and enhanced neurite outgrowth. In contrast, depleting $\mathrm{PrP}^{\mathrm{C}}$ or expressing disease-associated mutants of $\mathrm{PrP}^{\mathrm{C}}$ prevented RhoA inactivation and neurite outgrowth by interfering with the interaction

maintained in Dulbecco's modified Eagle's medium (DMEM) (Hyclone, Logan, UT, USA) supplemented with $10 \%$ heat-inactivated fetal bovine serum (FBS; Hyclone), $100 \mathrm{units} / \mathrm{ml}$ penicillin and $100 \mu \mathrm{g} / \mathrm{ml}$ streptomycin (Thermo Fisher Scientific, Rockford, IL, USA) at $37{ }^{\circ} \mathrm{C}$ under $5 \% \mathrm{CO}_{2}$. Transient transfections were carried out using the Lipofectamine 2000 reagent (Thermo Fisher Scientific) according to the manufacturer's directions. For siRNA transfection, ZW cells were transfected with siRNA targeting human PrP ( $150 \mathrm{pmol} / \mathrm{ml})$ for $72 \mathrm{~h}$ to silence PrP expression. PC12 cells stably expressing the pcDNA3.1/Zeo(+) vector or vector encoding human PrPs (WT; P102L, the most common GSS-causing mutation; M $\Delta 8$, octapeptide repeat deletions) were generated using the Lipofectamine 2000 reagent, followed by selection and maintenance in the presence of $250 \mu \mathrm{g} / \mathrm{ml}$ Zeocin (Thermo Fisher Scientific). PC12 cells were grown in RPMl 1640 medium (Hyclone) supplemented with $10 \%$ heat-inactivated horse serum (HS, Hyclone), 5\% FBS, 100 units $/ \mathrm{ml}$ penicillin and $100 \mu \mathrm{g} / \mathrm{ml}$ streptomycin at $37^{\circ} \mathrm{C}$ under $5 \% \mathrm{CO}_{2}$.
Animals. The Prnp-transgenic (Tga20) and Prnp-deficient mice (Zürich I) were kindly provided by Dr. C Weissmann (Department of Infectology, Scripps Florida, Jupiter, FL, USA) and Dr. A Aguzzi (Institute of Neuropathology, University Hospital of Zürich, Zürich, Switzerland), respectively. The WT control male C57BL/6J mice were purchased from Young Bio (Seongnam, Republic of Korea). The Tga20, Zürich I and WT control C57BL/6J mice were housed in a clean facility under natural light-dark cycle conditions (12-h/12-h light/dark cycle) and examined at 8-10 weeks of age. All experiments were performed in accordance with Korean laws and with the approval of the Hallym Medical Center Institutional Animal Care and Use Committee (HMC2015-0-0411-3).

Induction of neurite outgrowth in PC12 cells. To assess neurite outgrowth, the PC12 cells were plated at a density of $5 \times 10^{3}$ cells per well on $35 \mathrm{~mm}$ culture dishes coated with poly-D-lysine solution (Sigma-Aldrich). After $12 \mathrm{~h}$, 
the PC12 cells were incubated with $50 \mathrm{ng} / \mathrm{ml}$ NGF2.5S (Millipore) for the indicated times in DMEM medium containing with $1 \%$ heat-inactivated $\mathrm{HS}, 0.5 \%$ heatinactivated FBS, and $100 \mathrm{units} / \mathrm{ml}$ penicillin and $100 \mu \mathrm{g} / \mathrm{ml}$ streptomycin. The quantity of neurite bearing cells was determined by counting at least 100 single cells/3 arbitrary positions per dish. A cell was identified to as positive for neurite outgrowth if it had at least a twofold increased cell body diameter. Cells were visualized using a phase-contrast microscope (200x, Nikon TS100, Nikon, Tokyo, Japan).

Western blot analysis. Cells were collected and washed once with ice-cold phosphate-buffered saline (PBS) and lysed with modified RIPA buffer (50 mM Tris$\mathrm{HCl}(\mathrm{pH} 7.4), 150 \mathrm{mM} \mathrm{NaCl}, 1 \%$ Nonidet P-40, $0.25 \%$ sodium deoxycholate, $10 \mathrm{mM}$ $\mathrm{NaF}, 1 \mathrm{mM} \mathrm{Na} \mathrm{VO}_{4}, 1 \mathrm{mM}$ EDTA, and $1 \mathrm{mM}$ EGTA) supplemented with a protease inhibitor cocktail tablet (Roche, Indianapolis, IN, USA). The cell lysates were centrifuged at $13000 \times g$ for $10 \mathrm{~min}$, and the protein concentrations in the supernatants were analyzed using a BCA protein assay kit (Thermo Fisher Scientific). Equal amounts of proteins were separated using SDS-PAGE, transferred to PVDF membranes, and probed with the appropriate antibodies. Immunoreactive bands were visualized on digital images captured with an ImageQuant LAS4000 imager (GE Healthcare Life Sciences, Piscataway, NJ, USA) using EzwestLumi plus western blot detection reagent (ATTO Corporation, Tokyo, Japan), and the band intensities were quantified using ImageJ $(\mathrm{NIH})$ program (Bethesda, MD, USA). Statistical analyses were performed using GraphPad Prism4 (San Diego, CA, USA).

Immunocytochemistry. PC12 cells were treated with $50 \mathrm{ng} / \mathrm{ml} \mathrm{NGF2.5S}$ in DMEM media (supplemented with $1 \%$ heat-inactivated HS, $0.5 \%$ heat-inactivated FBS, and antibiotics) for the indicated times at $37{ }^{\circ} \mathrm{C}$ under $5 \% \mathrm{CO}_{2}$. The cells were washed with PBS and fixed with a $4 \%$ paraformaldehyde solution for $20 \mathrm{~min}$ at room temperature (RT). The cells were permeablized with $0.2 \%$ Triton X-100 for $10 \mathrm{~min}$, and then the samples were blocked with $5 \%$ normal goat serum and $1 \%$ BSA in PBS for $15 \mathrm{~min}$ at RT. For fluorescence labeling, the cells were incubated with rabbit polyclonal anti-RhoA (1:100; Santa Cruz Biotechnology) and goat polyclonal anti-PrP (1:200; Santa Cruz Biotechnology) antibodies overnight at $4{ }^{\circ} \mathrm{C}$. The cells were washed and incubated with fluorescein isothiocyanate-conjugated or rhodamine-conjugated anti-mouse or rabbit IgG $(1: 500)$ for $1 \mathrm{~h}$, at RT. The immunolabeled cells were examined using a LSM 700 laser confocal microscope (Zeiss, Oberkochen, Germany).

Immunoprecipitation. The cells were harvested and washed once with icecold PBS, and then lysed in modified RIPA buffer. The cell lysates were centrifuged for $10 \mathrm{~min}$ at $13000 \times \mathrm{g}$ and the supernatants were incubated with anti-RhoA, antip190RhoGAP, and anti-PrP $(3 F 10)^{57}$ antibodies for $2 \mathrm{~h}$ at $4{ }^{\circ} \mathrm{C}$. After antibody binding, protein A-conjugated Sepharose 4B beads (Thermo Fisher Scientific) were added for $2 \mathrm{~h}$ at $4{ }^{\circ} \mathrm{C}$. The beads were then washed three times with lysis buffer, and the bound proteins were eluted with $2 \times$ Laemmli sample buffer by boiling. The samples were electrophoresed and analyzed by western blot with anti-RhoA, anti-p190RhoGAP, and anti-PrP (3F4 or 3F10) ${ }^{57,58}$ antibodies.

GST-Rhotekin-RBD pull-down assay for activating RhoA. The cells were harvested and washed with PBS, and then lysed in binding/washing/lysis buffer (25 mM Tris- $\mathrm{HCl}$, pH 7.4, $150 \mathrm{mM} \mathrm{NaCl}, 5 \mathrm{mM} \mathrm{MgCl}$, $1 \%$ NP-40, $1 \mathrm{mM}$ DTT, $5 \%$ glycerol, $10 \mathrm{mM} \mathrm{NaF}, 1 \mathrm{mM} \mathrm{Na} \mathrm{VO}_{4}, 1 \mathrm{mM}$ EDTA, and $1 \mathrm{mM}$ EGTA) with a protease inhibitor cocktail tablet. The lysates were centrifuged at $13000 \times g$ for $10 \mathrm{~min}$ at $4{ }^{\circ} \mathrm{C}$. The supernatant was incubated with GST-Rhotekin-RBD to detect RhoA-GTP. The beads were washed three times with binding/washing/lysis buffer. The bound proteins were eluted with $2 \times$ Laemmli sample buffer by boiling. The samples were electrophoresed and analyzed by western blot with the anti-RhoA antibody.

In vitro loading of GDP and GTP $y$ S onto GTP-binding proteins. Cell lysates $(500 \mu \mathrm{g} / \mathrm{ml}$ protein in $500 \mu \mathrm{l})$ were incubated with $10 \mathrm{mM}$ EDTA (pH 8.0). Next, $0.1 \mathrm{mM}$ GTP $\gamma$ S or $1 \mathrm{mM}$ GDP was added to the cell lysates, and the lysates were incubated at $30^{\circ} \mathrm{C}$ for $15 \mathrm{~min}$ under constant agitation. The reaction was terminated by thoroughly mixing the sample with $\mathrm{MgCl}_{2}$ at a final concentration of $60 \mathrm{mM}$ on ice.

In vitro GST-tagged protein-protein interactions. The purified recombinant GST and GST-RhoA proteins $(10 \mu \mathrm{g} / \mathrm{ml}$ protein in $500 \mu \mathrm{l})$ were preincubated with glutathione (GSH)-sepharose $4 \mathrm{~B}$ beads for $2 \mathrm{~h}$ at $4{ }^{\circ} \mathrm{C}$ in a binding buffer (50 mM Tris- $\mathrm{HCl}$, pH 7.5, 1x PBS, and 10\% glycerol,) with a protease inhibitor cocktail tablet. To determine protein-protein interaction, GST and GSTRhoA beads were incubated with $1-4 \mu \mathrm{g}$ of purified human recombinant PrP (Hu-PrP) for $2 \mathrm{~h}$ at $4{ }^{\circ} \mathrm{C}$. After washing the beads, the bound proteins were eluted with $2 \times$ Laemmli sample buffer by boiling. The samples were electrophoresed and analyzed by western blot with the anti-PrP antibody.

Subcellular fractionation. Confluent cells were harvested, washed with ice-cold PBS, and lysed by passing through a 23-gauge syringe needle for 10 cycles in cold hypotonic buffer (10 mM Tris- $\mathrm{HCl}(\mathrm{pH} 7.4), 1 \mathrm{mM} \mathrm{DTT,} 5 \mathrm{mM} \mathrm{MgCl}_{2}$, $10 \mathrm{mM} \mathrm{KCl}, 10 \mathrm{mM} \mathrm{NaF}$, and $1 \mathrm{mM} \mathrm{Na}_{3} \mathrm{VO}_{4}$ ) with a protease inhibitor cocktail tablet. The lysates were centrifuged at $500 \times \mathrm{g}$ for $10 \mathrm{~min}$. The pellets that contained nuclei and nuclei-associated structures were solubilized with HEPES buffer ( $\mathrm{pH} 7.2$ ) containing $400 \mathrm{mM} \mathrm{NaCl}, 1 \mathrm{mM}$ EDTA, $1 \mathrm{mM}$ DTT, and the protease inhibitor cocktail and were agitated on ice for $30 \mathrm{~min}$. The postnuclear supernatants were centrifuged at $100000 \times \mathrm{g}$ for $1 \mathrm{~h}$ at $4{ }^{\circ} \mathrm{C}$ to separate the membrane pellet and the cytosolic fraction. The membrane pellets were washed with ice-cold PBS and suspended in RIPA buffer by rocking for $1 \mathrm{~h}$ at $4^{\circ} \mathrm{C}$, followed by centrifugation at $13000 \times \mathrm{g}$ for $10 \mathrm{~min}$ at $4^{\circ} \mathrm{C}$. The supernatant, containing the solubilized membrane proteins, was considered the membrane fraction.

F-actin sedimentation assay. Cells were harvested and washed with PBS, and then lysed in $0.1 \%$ Triton X-100 and F-actin stabilization PHEM buffer $(60 \mathrm{mM}$ PIPES, $25 \mathrm{mM}$ HEPES, $10 \mathrm{mM}$ EGTA, $2 \mathrm{mM} \mathrm{MgCl}$, pH 6.9) with a protease inhibitor cocktail. The cell lysates were carefully mixed and directly transferred into a TLA 100 centrifuge tube (Beckman Instruments, Palo Alto, CA, USA). The lysates were centrifuged at $100000 \times \mathrm{g}$ for $1 \mathrm{~h}$ at $4{ }^{\circ} \mathrm{C}$ in a table top ultracentrifuge (Beckman Instruments), which yielded a clear supernatant. At these high centrifugal forces, all F-actin in the system is expected to pellet, leaving G-actin in the supernatant. The F-actin pellet was washed twice in ice-cold PHEM buffer and suspended in SDS buffer. Protein concentration of the fractions was quantified using a BCA protein assay kit. Equal amounts of proteins were electrophoresed, and transferred to PVDF membrane for probing with anti- $\beta$-actin antibody. The densitometric quantification of the western blot determined the comparable levels of $\mathrm{G}$ - and $\mathrm{F}$-actin using Image $\mathrm{J}$ software.

Statistical analysis. The data are presented as the mean \pm S.E. of at least three independent experiments. Student's $t$-tests were used to compare groups using the GraphPad Prism4 program.

\section{Conflict of Interest}

The authors declare no conflict of interest.

Acknowledgements. This work was supported by the National Research Foundation of Korea (NRF) grant funded by the Korean Government (NRF-2013R1A1A2007071) and by a grant of the Korea Health Technology R\&D Project through the Korea Health Industry Development Institute (KHIDI), funded by the Ministry of Health and Welfare, Republic of Korea (H16C1085).

1. Bishop AL, Hall A. Rho GTPases and their effector proteins. Biochem J 2000; 348(Pt 2): 241-255.

2. Burridge K, Wennerberg K. Rho and Rac take center stage. Cell 2004; 116: 167-179.

3. Kim HJ, Kim JG, Moon MY, Park SH, Park JB. IאB kinase gamma/nuclear factor- $\kappa B-$ essential modulator (IKKgamma/NEMO) facilitates RhoA GTPase activation, which, in turn, activates Rho-associated KINASE (ROCK) to phosphorylate IKKbeta in response to transforming growth factor TGF- $\beta 1$. J Biol Chem 2014; 289: 1429-1440.

4. Kjoller L, Hall A. Signaling to Rho GTPases. Exp Cell Res 1999; 253: 166-179.

5. Govek EE, Newey SE, Van Aelst L. The role of the Rho GTPases in neuronal development. Genes Dev 2005; 19: 1-49.

6. Luo L. RHO GTPASES in neuronal morphogenesis. Nat Rev Neurosci 2000; 1: 173-180.

7. da Silva JS, Dotti CG. Breaking the neuronal sphere: regulation of the actin cytoskeleton in neuritogenesis. Nat Rev Neurosci 2002; 3: 694-704.

8. Tigyi G, Fischer DJ, Sebok A, Marshall F, Dyer DL, Miledi R. Lysophosphatidic acid-induced neurite retraction in $\mathrm{PC} 12$ cells: neurite-protective effects of cyclic AMP signaling. J Neurochem 1996; 66: 549-558.

9. Jeon CY, Moon MY, Kim JH, Kim HJ, Kim JG, Li Y et al. Control of neurite outgrowth by RhoA inactivation. J Neurochem 2012; 120: 684-698. 
10. Black SA, Stys PK, Zamponi GW, Tsutsui S. Cellular prion protein and NMDA receptor modulation: protecting against excitotoxicity. Front Cell Dev Biol 2014; 2: 45.

11. Aguzzi A, Baumann F, Bremer J. The prion's elusive reason for being. Annu Rev Neurosci 2008; 31: 439-477.

12. Llorens $F$, Carulla $P$, Villa A, Torres JM, Fortes $P$, Ferrer I et al. $\operatorname{PrP}(C)$ regulates epidermal growth factor receptor function and cell shape dynamics in Neuro2a cells. J Neurochem 2013; 127: 124-138.

13. Hundt C, Peyrin JM, Haik S, Gauczynski S, Leucht C, Rieger R et al. Identification of interaction domains of the prion protein with its $37-\mathrm{kDa} / 67-\mathrm{kDa}$ laminin receptor. EMBO J 2001; 20: 5876-5886.

14. West DC, Rees CG, Duchesne L, Patey SJ, Terry CJ, Turnbull JE et al. Interactions of multiple heparin binding growth factors with neuropilin-1 and potentiation of the activity of fibroblast growth factor-2. J Biol Chem 2005; 280: 13457-13464.

15. Zanata SM, Lopes MH, Mercadante AF, Haij GN, Chiarini LB, Nomizo R et al. Stressinducible protein 1 is a cell surface ligand for cellular prion that triggers neuroprotection. EMBO J 2002; 21: 3307-3316.

16. Spielhaupter $\mathrm{C}$, Schatzl HM. PrPC directly interacts with proteins involved in signaling pathways. J Biol Chem 2001; 276: 44604-44612.

17. Mouillet-Richard S, Ermonval M, Chebassier C, Laplanche JL, Lehmann S, Launay JM et al. Signal transduction through prion protein. Science 2000; 289: 1925-1928.

18. Schmitt-Ulms G, Legname G, Baldwin MA, Ball HL, Bradon N, Bosque PJ et al. Binding of neural cell adhesion molecules (N-CAMs) to the cellular prion protein. J Mol Biol 2001; 314: 1209-1225.

19. Santuccione A, Sytnyk V, Leshchyns'ka I, Schachner M. Prion protein recruits its neuronal receptor NCAM to lipid rafts to activate p59fyn and to enhance neurite outgrowth. J Cell Biol 2005; 169: 341-354.

20. Rieger R, Edenhofer $\mathrm{F}$, Lasmezas $\mathrm{Cl}$, Weiss $\mathrm{S}$. The human $37-\mathrm{kDa}$ laminin receptor precursor interacts with the prion protein in eukaryotic cells. Nat Med 1997; 3: 1383-1388.

21. Beraldo FH, Arantes CP, Santos TG, Machado CF, Roffe M, Hajj GN et al. Metabotropic glutamate receptors transduce signals for neurite outgrowth after binding of the prion protein to laminin gamma1 chain. FASEB J 2011; 25: 265-279.

22. Chen S, Mange A, Dong L, Lehmann S, Schachner M. Prion protein as trans-interacting partner for neurons is involved in neurite outgrowth and neuronal survival. Mol Cell Neurosci 2003; 22: 227-233.

23. Krebs B, Dorner-Ciossek C, Schmalzbauer R, Vassallo N, Herms J, Kretzschmar HA. Prion protein induced signaling cascades in monocytes. Biochem Biophys Res Commun 2006; 340: 13-22.

24. Loubet D, Dakowski C, Pietri M, Pradines E, Bernard S, Callebert J et al. Neuritogenesis: the prion protein controls beta1 integrin signaling activity. FASEB J 2012; 26: 678-690.

25. Alleaume-Butaux A, Nicot S, Pietri M, Baudry A, Dakowski C, Tixador P et al. Double-edge sword of sustained ROCK activation in prion diseases through neuritogenesis defects and prion accumulation. PLoS Pathogens 2015; 11: e1005073.

26. Kim BH, Kim Jl, Choi EK, Carp RI, Kim YS. A neuronal cell line that does not express either prion or doppel proteins. Neuroreport 2005; 16: 425-429.

27. Ellerbroek SM, Wennerberg K, Burridge K. Serine phosphorylation negatively regulates RhoA in vivo. J Biol Chem 2003; 278: 19023-19031.

28. Spiering D, Hodgson L. Dynamics of the Rho-family small GTPases in actin regulation and motility. Cell Adh Migr 2011; 5: 170-180.

29. Sit ST, Manser E. Rho GTPases and their role in organizing the actin cytoskeleton. J Cell Sci 2011; 124(Pt 5): 679-683.

30. Brouns MR, Matheson SF, Hu KQ, Delalle I, Caviness VS, Silver $\mathrm{J}$ et al. The adhesion signaling molecule p190 RhoGAP is required for morphogenetic processes in neural development. Development 2000; 127: 4891-4903.

31. Brouns MR, Matheson SF, Settleman J. p190 RhoGAP is the principal Src substrate in brain and regulates axon outgrowth, guidance and fasciculation. Nat Cell Biol 2001; 3: 361-367.

32. Arthur WT, Burridge K. RhoA inactivation by p190RhoGAP regulates cell spreading and migration by promoting membrane protrusion and polarity. Mol Biol Cell 2001; 12: 2711-2720.

33. Brown K, Mastrianni JA. The prion diseases. J Geriatr Psychiatry Neurol 2010; 23: 277-298.

34. Prusiner SB, DeArmond SJ. Molecular biology and pathology of scrapie and the prion diseases of humans. Brain Pathol 1991: 1: 297-310.

35. Kovacs GG, Budka H. Prion diseases: from protein to cell pathology. Am J Pathol 2008; 172 555-565.

36. Linden R, Martins VR, Prado MA, Cammarota M, Izquierdo I, Brentani RR. Physiology of the prion protein. Physiol Rev 2008; 88: 673-728.

37. Gallo G, Letourneau PC. Regulation of growth cone actin filaments by guidance cues. J Neurobiol 2004; 58: 92-102.

38. Letourneau PC. Actin in axons: stable scaffolds and dynamic filaments. Results Probl Cell Differ 2009; 48: 65-90

39. Tilve S, Difato F, Chieregatti E. Cofilin 1 activation prevents the defects in axon elongation and guidance induced by extracellular alpha-synuclein. Sci Rep 2015; 5: 16524
40. Ohashi K. Roles of cofilin in development and its mechanisms of regulation. Dev Growth Differ 2015; 57: 275-290.

41. Krause KH, Lambeth D, Kronke M. NOX enzymes as drug targets. Cell Mol Life Sci 2012; 69 2279-2282.

42. Walsh KP, Kuhn TB, Bamburg JR. Cellular prion protein: a co-receptor mediating neuronal cofilin-actin rod formation induced by beta-amyloid and proinflammatory cytokines. Prion 2014; 8: 375-380.

43. Graner E, Mercadante AF, Zanata SM, Martins VR, Jay DG, Brentani RR. Laminin-induced PC-12 cell differentiation is inhibited following laser inactivation of cellular prion protein. FEBS Lett 2000; 482: 257-260.

44. Hernandez-Rapp J, Martin-Lanneree S, Hirsch TZ, Pradines E, Alleaume-Butaux A, Schneider B et al. A PrP(C)-caveolin-Lyn complex negatively controls neuronal GSK3beta and serotonin 1B receptor. Sci Rep 2014; 4: 4881.

45. Auer M, Schweigreiter R, Hausott B, Thongrong S, Holtje M, Just I et al. Rho-independent stimulation of axon outgrowth and activation of the ERK and Akt signaling pathways by $\mathrm{C3}$ transferase in sensory neurons. Front Cell Neurosci 2012; 6: 43.

46. Hensel N, Ratzka A, Brinkmann H, Klimaschewski L, Grothe C, Claus P. Analysis of the fibroblast growth factor system reveals alterations in a mouse model of spinal muscular atrophy. PLOS ONE 2012; 7: e31202.

47. Arthur WT, Petch LA, Burridge K. Integrin engagement suppresses RhoA activity via a c-Srcdependent mechanism. Curr Biol 2000; 10: 719-722.

48. Nakahara H, Mueller SC, Nomizu M, Yamada Y, Yeh Y, Chen WT. Activation of beta1 integrin signaling stimulates tyrosine phosphorylation of p190RhoGAP and membrane-protrusive activities at invadopodia. J Biol Chem 1998; 273: 9-12.

49. Sharma SV. Rapid recruitment of 120 RasGAP and its associated protein, p190RhoGAP, to the cytoskeleton during integrin mediated cell-substrate interaction. Oncogene 1998; 17: 271-281.

50. Jeon CY, Kim HJ, Morii H, Mori N, Settleman J, Lee JY et al. Neurite outgrowth from PC12 cells by basic fibroblast growth factor (bFGF) is mediated by RhoA inactivation through p190RhoGAP and ARAP3. J Cell Physiol 2010; 224: 786-794.

51. Lang P, Gesbert F, Delespine-Carmagnat M, Stancou R, Pouchelet M, Bertoglio J. Protein kinase A phosphorylation of RhoA mediates the morphological and functional effects of cyclic AMP in cytotoxic lymphocytes. EMBO J 1996; 15: 510-519.

52. Forget MA, Desrosiers RR, Gingras D, Beliveau R. Phosphorylation states of Cdc42 and RhoA regulate their interactions with Rho GDP dissociation inhibitor and their extraction from biological membranes. Biochem J 2002; 361(Pt 2): 243-254.

53. Tkachenko E, Sabouri-Ghomi M, Pertz O, Kim C, Gutierrez E, Machacek M et al. Protein kinase A governs a RhoA-RhoGDI protrusion-retraction pacemaker in migrating cells. Nat Cell Biol 2011; 13: 660-667.

54. Raftopoulou M, Hall A. Cell migration: Rho GTPases lead the way. Dev Biol 2004; 265 23-32.

55. Shmerling D, Hegyi I, Fischer M, Blattler T, Brandner S, Gotz J et al. Expression of aminoterminally truncated $\operatorname{PrP}$ in the mouse leading to ataxia and specific cerebellar lesions. Cell 1998; 93: 203-214

56. Baumann F, Tolnay M, Brabeck C, Pahnke J, Kloz U, Niemann HH et al. Lethal recessive myelin toxicity of prion protein lacking its central domain. EMBO J 2007; 26: 538-547.

57. Kim BH, Lee HG, Choi JK, Kim JI, Choi EK, Carp RI et al. The cellular prion protein (PrPC) prevents apoptotic neuronal cell death and mitochondrial dysfunction induced by serum deprivation. Brain Res Mol Brain Res 2004; 124: 40-50.

58. Kascsak RJ, Rubenstein R, Merz PA, Tonna-DeMasi M, Fersko R, Carp RI et al. Mouse polyclonal and monoclonal antibody to scrapie-associated fibril proteins. J Virol 1987; 61: 3688-3693.

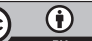

Cell Death and Disease is an open-access journal published by Nature Publishing Group. This work is licensed under a Creative Commons Attribution 4.0 International License. The images or other third party material in this article are included in the article's Creative Commons license, unless indicated otherwise in the credit line; if the material is not included under the Creative Commons license, users will need to obtain permission from the license holder to reproduce the material. To view a copy of this license, visit http://creativecommons.org/licenses/by/4.0/

(C) The Author(s) 2017 